\title{
OD SANKCJI DO SANKCJI. POLITYKA STANÓW ZJEDNOCZONYCH WOBEC ISLAMSKIEJ REPUBLIKI IRANU
}

Sankcje są częstym instrumentem wykorzystywanym w polityce wobec tzw. ,państw trudnych". Warunkiem wprowadzenia sankcji jest zgodność w ocenie wobec następujących kwestii: 1) złamane zostały normy prawa międzynarodowego; 2) występuje zagrożenie dla bezpieczeństwa międzynarodowego; 3) łamane są prawa człowieka i dochodzi do aktów ludobójstwa. Celem reżimu sankcji jest doprowadzenie do zmiany niepożądanej polityki państwa. Sankcje, mimo iż budzą wiele zastrzeżeń, były jednak uważane za znaczenie mniej kosztowny wariant nacisku na dany reżim polityczny, aniżeli użycie wobec niego bezpośredniej siły zbrojnej. Sankcje mogą być nakładane przez jedno państwo bądź grupę państw, mogą mieć one także szerszy charakter jak np. te przyjęte przez Radę Bezpieczeństwa ONZ. Sankcje wypełniły lukę pomiędzy akcją zbrojną a potępieniem. Jednym z problemów jest fakt, że sankcje bardzo rzadko przynoszą natychmiastowe rezultaty. Nakładane są na ogół na wiele lat i też niestety bardzo rzadko prowadzą do zmiany niepożądanych działań państwa, wobec którego zostały zaadresowane. Kolejnym problemem jest stopień przestrzegania reżimu sankcji przez państwa, które je nałożyły oraz niekiedy brak zgodności co do dalszego ich zaostrzania. Reżimy sankcji jako instrument są bardziej efektywne jeśli społeczność międzynarodowa jest jednomyślna, że niewłaściwe zachowanie państwa wymaga skorygowania i gotowa jest je dalej utrzymać czy nawet rozszerzać. Doświadczenia państw, na które nałożono sankcje ukazują, że mogą je obejść przez znajdowanie różnych luk, które mogą wynikać z faktu, że nie wszystkie państwa są w równym stopniu zaangażowane w utrzymaniu reżimu sankcji. Istotnym argumentem przeciwko sankcjom są koszty, które ponoszone są zarówno przez państwo/państwa nakładające, jak i przez te, wobec których są nakładane.

Bezpieczeństwo, ludobójstwo, proliferacja broni jądrowej czy terroryzm wydają się wystarczającymi powodami do nałożenia sankcji. Jak się okazuje w praktyce międzynarodowej bardzo rzadko udaje się wypracować consensus zwłaszcza w ramach Rady Bezpieczeństwa ONZ. Percepcja zagrożeń oraz polityka międzynarodowa są czynnikami ukazującymi wiele przeszkód mogących uniemożliwić wypracowanie takiej zgody. Uwarunkowane jest to nie tylko różnymi celami w polityce międzynarodowej, ale również związane jest to kosztami, które nie wszyscy chcą ponieść. W czasie zimnej wojny niezwykle rzadko sięgano po sankcje przede wszystkim ze względu na rozbieżności supermocarstw w polityce międzynarodowej i rywalizację pomiędzy nimi. W latach 1946-1990 jedynie dwa razy nałożone zostały sankcje przez RB ONZ. Pierwszy przypadek to Rodezja Południowa w 1966 r., a drugi to Republika Południowej Afryki 
w 1977 r. ${ }^{1}$ Po 1990 r. do sankcji jako instrumentu w polityce międzynarodowej zaczęto sięgać znacznie częściej. W latach 1990-2005 RB ONZ nałożyła ponad dwadzieścia różnego rodzaju reżimów sankcji ${ }^{2}$. Sankcje były nakładane przez RB ONZ, aby osiagnąć następujące cele: 1) nakłonienie okupanta do wycofania swoich sił (rezolucja RB ONZ nr 661 wobec Iraku); 2) powstrzymanie proliferacji broni jądrowej (np. RB ONZ nr 418 wobec RPA); 3) zwalczanie międzynarodowego terroryzmu (np. RB ONZ $\mathrm{nr} 748$ wobec Libii); 4) powstrzymanie łamania praw człowieka (np. RB ONZ nr 841 wobec Haiti); 5) doprowadzenie do procesu pokojowego (np. RB ONZ nr 788 i 1521 wobec Liberii).

Testem skuteczności reżimu sankcji był Irak. W latach 1990-2003 wyraźnie zarysował się podział w RB ONZ pomiędzy USA, Wielką Brytanią a Rosją, Francją i China$\mathrm{mi}^{3}$. Wyraziciele pierwszej grupy uważali, że sankcje są głównie po to, aby doprowadzić do upadku dyktatury i pożądanej zmiany politycznej, natomiast dla grupy stałych członków Rady sankcje mogły zostać zniesione po rozbrojeniu Iraku z broni masowego rażenia ${ }^{4}$. Już w czasie prezydentury W. Clintona było wyraźnie widać irytację USA i brak wiary w skuteczność sankcji, dlatego prowadzono jednostronne, niekonsultowane w ramach RB ONZ działania, jak np. „karzące bombardowania” w ramach m.in. operacji „Pustynny Lis” oraz przez wydatne wspieranie irackiej opozycji. Centralna Agencja Wywiadowcza (CIA) bez powodzenia planowała zorganizowanie kilku akcji, które miały ułatwić zmianę polityczną w Iraku ${ }^{5}$. Przedłużające się sankcje wobec reżimu S. Husajna, nie tyle uderzały we władze w Bagdadzie, co bardziej w społeczeństwo irackie. Dochody Iraku zmalały o 2/3 i pograżyły jeszcze bardziej gospodarkę tego państwa. Sytuacja gospodarcza Iraku była w fatalnej kondycji nie tylko z powodu sankcji, lecz także konfliktów z ostatnich lat ${ }^{6}$. Problem pogarszającej się w dramatyczny sposób sytuacji ludności Iraku, z całą siłą uwypuklił dylemat, że sankcje pogłębiają ubóstwo społeczeństwa irackiego oraz uniemożliwiają poprawę przestarzałej infrastruktury tego ${ }^{7}$. Próbą rozwiązania tego problemu było wprowadzenie programu humanitarnego „ropa za żywność” w ramach rezolucji nr 986 RB ONZ. Program nadzorowany

1 J. M. Farrall, United Nation Sactions and the Rule of Law, Cambridge 2007, s. 3.

2 P. Andreas, Criminalizing Consequences of Sanctions: Embargo Busting and Its Legacy, „International Studies Quarterly" 2005, Vol. 45, s. 336.

${ }^{3}$ G. Sick, The United States in the Persian Gulf, w: The Middle East and the United States. A Historical and Political Reassessment, ed. D. W. Lesch, Boulder 2005, s. 323.

${ }^{4}$ Szerzej na temat różnic: R. Fiedler, Od przywództwa do hegemonii. Polityka Stanów Zjednoczonych wobec bliskowschodniego obszaru niestabilności w latach 1991-2009, Poznań 2010, s. 164.

5 Zob.: D. Oberdorfer, US Had Covert Plan to Oust Iraq's Saddam, Bush Adviser Asserts; Effort to Remove Leader Came' Pretty Close', „Washington Post”, 20.01.1993.

6 Irak utracił dochody ze sprzedaży ropy pomiędzy 175 a 250 mld USD. Za: A. Al-Roubaie, W. Elali, The Financial Implications of Economic Sanctions on Iraq, „Arab Studies Quarterly”, 22.06.1995, http://www.highbeam.com/doc/1G1-17716344.html (10.03.2013).

7 W „The Economist” z maja $2001 \mathrm{r}$. oceniono dekadę funkcjonowania reżimu sankcji oraz ich wpływ na gospodarkę iracka; od 1991 r. wzrosła o 160\% śmiertelność wśród noworodków, przemysł znalazł się w zapaści z braku inwestycji. W konkluzji argumentem przeciw dotychczasowemu reżimowi sankcji było stwierdzenie, iż zamiast osłabić militarnie Irak, pogrążyły gospodarkę iracką w kryzysie i były coraz większym obciążeniem dla Irakijczyków. Zob.: Can sanctions be smarter? America's Policy on Iraq and Iran, „The Economist”, 26.05.2001. 
przez ONZ umożliwiał Irakowi kwartalną sprzedaż ropy za 1 mld USD i zakup za tę kwotę żywności i lekarstw ${ }^{8}$.

Pomimo katastrofalnej sytuacji gospodarczej reżim S. Husajna przetrwał, a jego podstawy wydawały się nie tyko nienaruszone, ale nawet wzmocnione. Doświadczenia irackie, ale także w innych przypadkach podważyły twierdzenie, że wobec pogłębiającej się współzależności wynikającej z procesu globalizacji, sankcje ekonomiczne, handlowe czy finansowe są znacznie bardziej dotkliwe i mogą doprowadzić nawet do poważnego kryzysu uderzającego w gospodarkę danego państwa. Istotne jest to szczególnie w przypadku Korei Północnej odpornej na sankcje, bowiem nie jest tak uzależniona od czynników zewnętrznych. Według Roberta Gilpina czy Roberta Pape’a, ekonomiczne sankcje w niewielu przypadkach doprowadziły do zmiany polityki autorytarnego reżimu, w którego były wymierzone ${ }^{9}$. David Baldwin ukuł nawet twierdzenie mówiące o ,paradoksie sankcji”, polegającym na tym, że państwa mimo ewidentnej nieskuteczności nakładanych sankcji, wprowadzają kolejne tylko dlatego, że opcja militarna była $\mathrm{z}$ różnych względów nie do przyjęcia ${ }^{10}$. Opinie tych badaczy wynikały głównie z obserwacji skutków sankcji w czasie zimnej wojny, jak i z doświadczeń lat dziewięćdziesiątych XX w. Wątpliwości te wydają się podważać sens sankcji, jeśli w większości przypadków nie doprowadziły do pożądanych przez społeczność międzynarodową zmian w zachowaniu państwa, wobec którego były adresowane. Nie przysłania to jednak faktu, że jednak doszło do poważnego osłabienia nie tylko potencjału ekonomicznego, lecz również militarnego Iraku. Po 2003 r. same Stany Zjednoczone mogły przekonać się jak poważnie został osłabiony Irak z powodu utrzymywanych przez kilkanaście lat sankcji. Nie istniały arsenały broni masowej zagłady, a posiadany potencjał militarny był nie tylko przestarzały, ale przede wszystkim nie mógł stanowić zagrożenia wobec Arabii Saudyjskiej czy Iranu. Irak stracił swoją zdolność bojową, ale ceną było pogorszenie i tak niełatwej sytuacji ludności, a reżim dyktatorski przetrwał. Nie było wewnętrznej siły, która byłaby zdolna odsunąć Saddama Husajna od władzy.

W przypadku Iranu nie udało się USA wypracować consensusu w RB ONZ za wprowadzeniem sankcji ekonomicznych nakładających embargo na zakup irańskiej ropy.

Celem artykułu jest analiza instrumentu sankcji oraz ukazanie ich konsekwencji we wzajemnych relacjach pomiędzy Iranem a USA, a w szczególności udzielenie odpowiedzi:

1. Dlaczego sankcje są najczęściej wykorzystywanym przez USA instrumentem presji wobec Iranu?

${ }^{8}$ ONZ kontrolowała, czy rzeczywiście pieniądze pochodzące ze sprzedaży ropy, były kierowane na zakup artykułów na potrzeby ludności cywilnej. K. Clark, Harvesting Hope. Effects of the Iraq United Nations Oil for Food Deal, „The Middle East”, 1.10.1996, http://www.highbeam.com/doc/1G1-18827073.html (10.03.2013). Por.: Iraq a Chronology of UN Inspections and an Assessment of Their Accomplishments, „Arms Control Today”, 1.10.2002.

9 H. Bienen, R. Gilpin, Economic Sanctions as a Response to Terrorism, „,The Journal of Strategic Studies” 1980, No. 3, s. 89-98. Por.: R. Pape, Why Economic Sanctions Do Not Work, „International Security" 1997, No. 22, s. 110.

10 D. Baldwin, The Sanctions Debate and the Logic of Choice, „International Security” 1999/2000, Vol. 24, No. 3, s. 81. 
2. W jakim stopniu sankcje wpływają na opóźnienie irańskiego programu atomowego po roku 2002?

3. Jaki mogą mieć wpływ na zmianę reżimu w Iranie?

\section{SANKCJE W POLITYCE USA WOBEC IRANU W LATACH 1979-2002}

Przed rewolucją islamską w Iranie, w polityce USA państwo to odgrywało istotną rolę jako jeden ze strategicznych sojuszników w regionie, obok Arabii Saudyjskiej, Turcji oraz Izraela. Wybuch i przebieg rewolucji doprowadził do poważnego kryzysu w relacjach Iranu z USA. 4 listopada 1979 r. doszło do wtargnięcia i zajęcia ambasady USA w Teheranie oraz wzięcia kilkudziesięciu amerykańskich zakładników. Administracja J. Cartera nie zdawała sobie sprawy, że kryzys z zakładnikami będzie trwał aż 444 dni. 5 listopada 1979 r. dobyło się pierwsze spotkanie w Waszyngtonie specjalnego komitetu koordynującego w sprawie zakładników amerykańskich w Iranie. W rozważanych opcjach brano pod uwagę zarówno operację odbicia zakładników oraz różnego rodzaju sankcje ekonomiczne, których skutki miały skłonić stronę irańską do negocjacji i porozumienia: uwolnienie zakładników w zamian za zniesienie sankcji. Sankcjom ekonomicznym przyświecał jeszcze jeden cel, a mianowicie zabezpieczenie dla amerykańskich firm, które poniosły straty z powodu rewolucji i zmiany polityki ze strony władz w Teheranie. Amerykański prezydent dysponował instrumentem zwanym International Emergency Economic Powers Act (IEEPA), który został wprowadzony dla ochrony banków amerykańskich przed gwałtownym wycofaniem z ich kont przez państwa OPEC petrodolarów ${ }^{11}$. W latach siedemdziesiątych $\mathrm{XX}$ w. ceny ropy naftowej znacznie wzrosły i państwa eksportujące ten surowiec, zaczęły lokować gotówkę w ogromnych ilościach w bankach amerykańskich. Zbyt raptowne wycofanie gotówki mogło zagrozić płynności finansowej banków, a nawet doprowadzić do turbulencji w systemie finansowym USA. System bankowy zaczął być niebezpiecznie zależny od kapitału zagranicznego. Dlatego IEEPA wyposażała amerykańskiego prezydenta w możliwość zamrożenia aktywów finansowych obcych instytucji finansowych, w sytuacji „,gdy doszło do naruszenia interesów USA i zagrożenia bezpieczeństwa ekonomicznego". Powołując się na ten instrument, 14 listopada 1979 r. prezydent Carter wydał decyzję o zablokowaniu 12 mld USD aktywów irańskich ulokowanych w amerykańskich bankach zarówno w Stanach Zjednoczonych, jak i poza nimi. Już 7 listopada prezydent nałożył embargo na zakup irańskiej ropy, przed nim obroty dzienne sprzedaży ropy do USA wynosiły prawie $14 \mathrm{mln}$ USD. Ograniczono import z Iranu oraz amerykański eksport do tego państwa, poza żywnością, lekarstwami i odzieżą ${ }^{12}$. Ostatecznie 7 kwietnia 1980 r. doszło do zerwania stosunków dyplomatycznych USA z Iranem.

Sankcje dodatkowo osłabiły Iran, który znajdował się już w bardzo trudnej sytuacji nie tyko z powodu rewolucji, ale także trwającej od września 1980 r. wojny z Irakiem.

11 S. Fayazmanesh, The United States and Iran. Sanctions, wars and the policy of dual containment, London-New York 2008, s. 13.

12 Szerzej: A. J. Pierre, Arms Sales: The New Diplomacy, „Foreign Affairs”, Winter 1981/2, s. $259-263$. 
W latach 1979-1981 produkcja ropy zmniejszyła się z poziomu 5,9 mln baryłek ropy dziennie (przed rewolucją) do zaledwie 700 tysięcy ${ }^{13}$. Szczególnie ten drugi czynnik ukazywał, jak poważne konsekwencje mają sankcje amerykańskie na potencjał militarny Iranu. Władze w Teheranie dążyły do jak najszybszego odblokowania depozytów irańskich w bankach amerykańskich. Stwarzało to płaszczyznę do negocjacji. Pojawia się zasadnicza kwestia - dlaczego kryzys z zakładnikami amerykańskim przetrzymywanymi w Teheranie trwał tak długo. Odpowiedzi należy doszukiwać się w sytuacji wewnętrznej w Iranie. Rozgrywanie kartą zakładników przede wszystkim miało przysłużyć się i mocno się przyczyniło do przejęcia przez fundamentalistów szyickich władzy w Iranie. Jednym z najbardziej eksponowanych wątków rewolucji islamskiej był anty-amerykanizm. Popierając zajęcie ambasady USA, Chomeini stał się bohaterem nie tylko w Iranie. Udało mu się przez ten kryzys doprowadzić do upokorzenia supermocarstwa i ukazania jego niezdolności do zmuszenia Iranu do uwolnienia zakładników $^{14}$. Po osiąnnięciu swoich zamierzeń w polityce wewnętrznej związanych z wprowadzeniem teokracji, strona irańska okazała się bardziej otwarta na negocjacje z USA. Istotną rolę w nich odegrały mediacje Algierczyków. 19 stycznia 1981 r. zawarto porozumienie algierskie, wieńczące kryzys z zakładnikami amerykańskimi. Z odblokowanej sumy 12 mld USD do Iranu powróciło niecałe 3 mld. W Hadze, w ramach Stałego Trybunału Arbitrażowego, utworzono specjalny trybunał ds. roszczeń, który rozpatrzył do tej pory ponad 4,5 tysiąca roszczeń z powództwa prywatnego na łączną kwotę ponad 2,5 mld USD ${ }^{15}$.

Kryzys związany z zakładnikami amerykańskimi, odcisnął poważne piętno w stosunkach amerykańsko-irańskich. Strona amerykańska od czasu kryzysu zaczęła postrzegać Iran w kategoriach poważnego zagrożenia dla interesów USA w Zatoce Perskiej. W strategii amerykańskiej wobec Iranu dominowało przekonanie o izolowaniu i powstrzymywaniu tego państwa nie tylko przed sięgnięciem do broni masowej zagłady, lecz również po regionalną hegemonię. Mało elastyczne podejście USA wobec Iranu wynikało z przeżytej traumy oraz upokorzenia. W Waszyngtonie uważano, że władze irańskie prowadzą nieodpowiedzialną politykę, która stanowi poważne zagrożenie dla Arabii Saudyjskiej i innych monarchii w Zatoce Perskiej oraz Izraela. Nałożone jednostronnie przez administrację J. Cartera sankcje na Iran miały pełnić określone role:

1) osłabić politycznie teokratyczny reżim i nawet w dłuższej perspektywie doprowadzić do zmiany politycznej;

2) zmniejszyć oddziaływanie rewolucyjnego Iranu na region;

3) uniemożliwić Iranowi zdobycie militarnej przewagi w wojnie z Irakiem.

Po ponad trzydziestu latach zasadnicze podejście USA wobec Iranu nie uległo zmianie. Sankcje i embargo na sprzedaż broni wydawały się środkiem, który w dalszej

13 S. Bakhash, The Reign of the Ayatollahs: Iran and the Islamic Revolution, New York 1990, s. 230 .

14 B. Moin, Khomeini: Life of the Ayatollah, London 1999, s. 226-227.

15 Szerzej: W. Christopher, R. M. Mosk, The Iranian Hostage Crisis and the Iran-U.S. Claims Tribunal: Implications for International Dispute Resolution and Diplomacy, „Pepperdine Dispute Resolution Law Journal” 2012, Vol. 7, Issue 2, s. 165-174. 
perspektywie miał doprowadzić do zmiany politycznej w Iranie. W 1992 r. przyjęto Iran-Iraq Arms Non-Proliferation Act, którego celem było ograniczenie zakupu przez Iran broni konwencjonalnej. Ustawa przewidywała sankcje wobec firm zagranicznych sprzedających elementy broni masowej zagłady oraz zaawansowaną broń konwencjonalną (czołgi, myśliwce, łodzie podwodne) do Iranu ${ }^{16}$.

Po ataku terrorystycznym na bazę marines w Bejrucie 23 października 1983 r. w styczniu 1984 r. Iran, którego podejrzewano za współudział w przygotowywaniu tego zamachu, został wpisany przez Departament Stanu na listę państw wspierających terroryzm. Począwszy od 1993 r. w corocznej publikacji Patterns of Global Terrorism, wydawanej przez Departament Stanu, zaczęto określać Iran najbardziej niebezpiecznym państwem wspierającym terroryzm ${ }^{17}$.

W czasie operacji „Pustynna Burza” Iran okazał życzliwą neutralność ${ }^{18}$. W wyniku tej operacji osłabiony został reżim S. Husajna, który przez władze w Teheranie uznawany był za najpoważniejsze regionalne zagrożenie. Nie uszło jednak uwadze władz. irańskich pojawienie się zwłaszcza na terytorium Arabii Saudyjskiej amerykańskich baz wojskowych. Polityka USA wobec Iraku oraz Iranu opierała się na strategii podwójnego powstrzymywania (dual containment). Polegała na politycznym, gospodarczym oraz militarnym powstrzymywaniu tych dwóch państw. W przypadku Iraku było wsparcie RB ONZ w utrzymaniu reżimu sankcji, z kolei wobec Iranu, USA nie mogły liczyć na szeroką koalicję międzynarodową akceptującą amerykańskie stanowisko wobec Iranu ${ }^{19}$. Strategia podwójnego powstrzymywania miała wiele ograniczeń: 1) nie uwzględniała istotnych różnic pomiędzy Iranem a Irakiem i rywalizacji pomiędzy nimi; 2) izolowanie zarówno Iraku oraz Iranu było kosztownym i obciążającym przedsięwzięciem dla USA wykluczającym opcję, iż dwa te państwa powinny same wypracować względem siebie model równowagi; 3) sankcje były w zasadzie jedynym instrumentem w strategii wobec Iranu; 4) w przypadku Iranu podwójne powstrzymywanie mogło nie zyskać wsparcia w RB ONZ i w ten sposób było jak się okazało jednostronnym działaniem USA; 5) uniemożliwiało dostęp amerykańskich przedsiębiorstw do irańskiego rynku, na czym korzystały nieamerykańscy przedsiębiorcy.

Mimo, że praktycznie nie było bezpośredniej wymiany handlowej pomiędzy Iranem a USA, amerykańskie koncerny naftowe jak Conoco przez swoich zagranicznych przedstawicieli dokonywały zakupu irańskiej ropy. W 1995 r. Conoco zawarł z Iranem kontrakt na rozwój wydobycia ropy w irańskiej strefie przybrzeżnej. Po zapowiedzi

${ }^{16}$ U.S. Department of State, Iran-Iraq Arms Non-Proliferation Act, http://www.state.gov/t/isn/c15237.htm (9.02.2013).

17 Patterns of Global Terrorism 1993, U.S. Department of State, Washington, April 1994, s. 1.

${ }_{18}$ Reżim Saddama Husajna podjął próbę uratowania myśliwców irackich w Iranie, aby uchronić je przed rakietami sił koalicji. Władze irańskie zarekwirowały samoloty jako zaległe wypłaty za szkody wynikające z wojny iracko-irańskiej 1980-1988. Zob.: M. Farhang, A Triangle of Realpolitik, Iran, Iraq and the United States, „The Nation”, 17.03.2003.

19 Autorami tej strategii byli w administracji W. Clintona znani wieloletni specjaliści ds. Bliskiego Wschodu: Martin Indyk - pierwszy dyrektor Near East and Soth Asian Affairs oraz Anthony Lake, pełniący wówczas funkcję specjalnego asystenta prezydenta ds. Narodowego Bezpieczeństwa. Szerzej: M. Indyk, The Clinton Administration's Approach to the Middle East, Soref Symposium at the Washington Institute for Near East Policy, 18.05.1993, http://www.washingtoninstitute.org/pubs/soref/indyk.htm (10.03.2013). 
administracji W. Clintona nałożenia zakazu na wszelkie inwestycje i handel firm amerykańskich z Iranem, Conoco wycofało się z planowanej inwestycji, jego miejsce zajął francuski Total $^{20}$. Plany koncernu naftowego pokrzyżowała polityka USA wobec Iranu. Zaostrzenie sankcji przez administrację W. Clintona było reakcją na nasilającą się kampanię terroryzmu samobójczego ze strony Hamasu, Islamskiego Dżihadu oraz Hezbollahu, organizacji wpieranych przez Iran, wymierzonego w Izrael. Ponadto Iran zawarł kontrakt z Rosją na dokończenie reaktora cywilnego w Buszerze ${ }^{21}$. Ostatecznie w maju 1995 r. przedstawiciele amerykańskiej administracji zdecydowali się na nałożenie całkowitego embarga na handel i inwestowanie przez firmy amerykańskie w Iranie. Embargo oznaczało całkowite odcięcie gospodarki irańskiej od firm amerykańskich oraz uniemożliwiło tym ostatnim nawet pośredniczenie w handlu ropą z Iranu. Nakładając to ograniczenie, prezydent powołał się na IEEPA, które już wcześniej było wykorzystywane w sprawie Iranu. Na przełomie 1999-2000 wysyłając pozytywny sygnał wobec reformatorskiego prezydenta Iranu Mohammada Chatamiego, administracja W. Clintona wycofała się z embarga.

W 1996 r. w Waszyngtonie uznano, że dotychczasowe sankcje nie zmieniły w żaden sposób „zachowania” Iranu, dlatego zdecydowano się na przyjęcie przez kongres USA ustawy Iran and Libya Sanctions Act (ILSA) ${ }^{22}$. Celem ILSA była izolacja Iranu, tak by w znaczący sposób doszło do zmniejszenia produkcji ropy i gazu w tym państwie. W ramach tej ustawy prezydent USA mógł nałożyć sankcje na jakąkolwiek zagraniczną firmę inwestującą w Iranie więcej aniżeli $40 \mathrm{mln}$ USD w celu unowocześnienia jego infrastruktury ${ }^{23}$. Problemem USA była jednostronność reżimu sankcji ekonomicznych, do których nie chcieli się również przyłączyć partnerzy z Europy Zachodniej oraz z Azji. Ubocznym skutkiem sankcji było wyłączenie firm amerykańskich z rynku irańskiego na rzecz konkurentów europejskich i azjatyckich. ILSA wywołał kontrowersje oraz krytykę polityki amerykańskiej wobec Iranu nie tylko ze strony Rosji i ChRL, ale także sojuszników USA ${ }^{24}$.

Podejście władz USA wobec Iranu pod względem używanej retoryki uległo nawet zaostrzeniu w czasie administracji G. W. Busha. Nadal utrzymywano reżim sankcji oraz blokowano przystapienie Iranu do Światowej Organizacji Handlu. Jednak na zmianę dotychczasowej strategii wobec Iranu mogły mieć wpływ następujące wydarzenia:

1) spontaniczna reakcja Irańczyków po 11 września 2001 r. w solidaryzowaniu się z ofiarami ataków terrorystycznych w USA, zdawała się nieco ocieplić wizerunek Iranu w USA. Żałoba zaprezentowana przez teherańczyków kontrastowała z tym co działo się w sąsiednich państwach muzułmańskich;

20 R. Fiedler, Od przywództwa..., op. cit., s. 172.

21 Rosja zdobyła kontrakt na budowę reaktora atomowego w Buszerze o wartości $800 \mathrm{mln}$ USD. Zob.: H. Estelami, A Study of Iran's Responses To U.S. Economic Sanctions, „,Middle East Review of International Affairs" (MERIA) 1999, Vol. 3, No. 3, http://meria.idc.ac.il/journal/1999/issue3/jv3n3a5.html/ (10.03.2013).

${ }^{22}$ Can sanctions be smarter? America's Policy on Iraq and Iran, „The Economist”, 26.05.2001.

23 H. Estelami, A Study of Iran's Responses To U.S. Economic Sanctions, op. cit.

24 R. G. Alexander, Iran and Libya Sanctions Act of 1996: Congress Exceeds Its Jurisdiction to Prescribe Law, „Washington and Lee Law Review” 1997, Vol. 54, Issue 4, http://scholarlycommons.law.wlu.edu/cgi/viewcontent.cgi?article=1635\&context=wlulr (10.02.2013). 
2) współpraca amerykańsko-irańska związana z odsunięciem talibów od władzy w Afganistanie. Irańczycy w przeciwieństwie do Rosji i Pakistanu nie sprzeciwili się amerykańskiej operacji wojskowej „Trwała Wolność”. Można stwierdzić, że wyszli nawet poza ramy, „życzliwej neutralności”, dostarczyli Amerykanom swoje dane wywiadowcze na temat Al-Kaidy i talibów, deportowali setki bojowników, którzy nielegalnie przekroczyli granicę afgańsko-irańską. Kennneth M. Pollack były analityk CIA dodał również, iż Iran zaproponował wykorzystanie we wschodnim Iranie lotnisk dla usprawnienia amerykańskiej logistyki transportowej do Afganistanu, wykorzystanie portu w Chah Bahar do przyjmowania pomocy humanitarnej dla Afganistanu i zadeklarował pomoc w akcji poszukiwawczo-ratowniczej dla załóg samolotów, które rozbiły się bądź musiały awaryjnie wylądować na terytorium Iranu ${ }^{25}$.

Pomimo wydawało się dość znaczącego postępu w trudnych relacjach amerykańsko-irańskich, niestety nie udało się doprowadzić do przełomu. Powrotem do zaostrzonej retoryki, był incydent ze statkiem Karine $A$, na pokładzie którego służby izraelskie 3 stycznia 2002 r. znalazły arsenał broni dla Autonomii Palestyńskiej, która była wyprodukowana w Iranie ${ }^{26}$. W orędziu prezydenta G. W. Busha, wygłoszonym w styczniu 2002 r. przed Kongresem, Iran został włączony obok Korei Północnej i Iraku do „osi zła” (ang. axis of evil). Symbolicznym zakończeniem ze strony Iranu krótkiej współpracy z USA w sprawie Afganistanu było zakończenie aresztu domowego warlordowi Gulbuddinowi Hekmatyarowi, który mógł z Iranu wyjechać do Afganistanu i zacząć organizować opór wymierzony w nowoutworzony rząd i siły amerykańskie ${ }^{27}$. Iran włączył się również we wspieranie talibów, by osłabić działania misji ISAF w Afganistanie. Najpoważniejszym dla władz w Teheranie zagrożeniem był natomiast wzrost liczebności wojsk i baz amerykańskich w Zatoce Perskiej, wręcz powodujący poczucie okrążenia zarówno od flanki irackiej po 2003 r., jak i afgańskiej po 2001 r. Chwilowy okres taktycznej współpracy nie zmienił polityki USA wobec Iranu i na odwrót. Utrzymano dotychczasowy kurs, oprócz podnoszonego przez Waszyngton argumentu o wspieraniu przez to państwo terroryzmu, pojawiła się dodatkowa kwestia - programu atomowego, która zdominuje politykę USA wobec Iranu.

\section{SANKCJE W STRATEGII USA WOBEC IRAŃSKIEGO PROGRAMU ATOMOWEGO PO 2002 R.}

Jednym z argumentów inwazji przeciwko Irakowi w 2003 r. były rzekome arsenały broni masowej zagłady zgromadzonej przez reżim Saddama Husajna. Zarzuty okazały się bezpodstawne. Amerykańskie doświadczenia z Irakiem, olbrzymie koszty

25 K. M. Pollack, The Persian Puzzle: The Conflict between Iran and America, Random House 2005 , s. 346.

26 Ibidem, s. 351.

27 Za ujęcie Hekmatyara była nagroda w wysokości 25 mln USD. Zob.: S. Eghraghi, Hekmatyar: The Wild Card in Afghanistan, „Asia Times”, 7.01.2004, http://www.atimes.com/atimes/Central_Asia/FA07Ag01.html (10.02.2013). 
przedłużającej się okupacji, po raz kolejny przypomniały, iż są bardziej bezpieczne instrumenty w wywieraniu presji, a do nich oczywiście zaliczały się różnego rodzaju sankcje. Kolejnym argumentem za sankcjami był fakt, że przez wiele lat w poważny sposób osłabiły iracki potencjał militarny. W tym kontekście kontynuowanie polityki nakładania kolejnych sankcji wydawało się najlepszym rozwiązaniem wobec Iranu. Celem dyplomacji USA było zyskanie możliwie jak najszerszej koalicji międzynarodowej i zdobycie autoryzacji RB ONZ. Powód wydawał się istotny, bowiem w sierpniu 2002 r. opozycyjna wobec władz irańskich, Narodowa Rada Oporu Iranu, poinformowała opinię międzynarodową o dwóch tajnych obiektach atomowych w pobliżu Natanzu oraz Araku, które służą do wzbogacania uranu i produkcji ciężkiej wody ${ }^{28}$. W grudniu 2003 r. władze irańskie wyraziły zgodę na podpisanie Protokołu Dodatkowego do Układu o Nieproliferacji Broni Jądrowej (NPT), zwiększający uprawnienia inspekcyjne Międzynarodowej Agencji Energii Atomowej (IAEA) ${ }^{29}$. Był to sukces przede wszystkim dyplomacji europejskiej. Trzy państwa UE: Francja, Niemcy i Wielka Brytania (E-3) prowadziły negocjacje z Iranem. Celem było całkowite zawieszenie przez Iran procesu wzbogacania uranu. Natomiast władze w Teheranie uważały, że europejscy partnerzy rozmów ostatecznie zgodzą się na to, że Iran będzie mógł nisko wzbogacać uran do poziomu 2,5-5\% jedynie do celów cywilnych. Nie doszło do przełomu, bowiem jedna, jak i druga strona negocjacji upierała się przy swoim stanowisku. Istniało podejrzenie, że Iran rozwijając proces wzbogacania uranu, będzie go mógł dalej przetwarzać, by w końcu uzyskać materiał do wyprodukowania broni jądrowej. Dyplomaci europejscy proponowali stronie irańskiej, że proces wzbogacania uranu powinien odbywać się poza Iranem. Ostatecznie ta propozycja została przez Iran odrzucona.

Narastający kryzys dawał podstawy do zwrócenia uwagi na problem irańskiego programu atomowego ze strony Rady Bezpieczeństwa ONZ. Przemawiało za tym kilka wątpliwości: 1) dlaczego zdecydowano się na budowę fabryki do produkcji ciężkiej wody w Araku, która nie jest potrzebna w rozwoju cywilnego programu atomowego?; 2) dlaczego Iran rozbudowuje obiekt do wzbogacania uranu w Natanzu?; 3) dlaczego strona irańska uniemożliwiła inspektorom IAEA zwizytowanie zakładów elektrycznych Kayale w Teheranie w czerwcu 2003 r. $^{30}$ ?

${ }^{28}$ Irański program atomowy wzbudził zainteresowanie społeczności międzynarodowej w sierpniu 2002 r. za sprawą opozycyjnego ugrupowania Narodowa Rada Oporu Iranu, które doniosło o nowych obiektach atomowych, takich jak: ośrodek służący do wzbogacania uranu w Natanz oraz zakładu produkcji ciężkiej wody w Arak. Praktycznie od końca 2002 r. narasta zaniepokojenie wokół irańskiego programu atomowego. Można zwrócić uwagę na trzy wątpliwości podnoszone w związku z tym programem: 1) strona irańska zataiła istnienie innych obiektów, poza tymi, które zadeklarowała inspektorom MAEA; 2) rozwijanie aspektu militarnego wraz z systemem rakietowym prowadzone jest równolegle z programem; 3) z ekonomicznej perspektywy koszt wzbogacania uranu jest bardzo wysoki i prawdopodobnie odpowiedzią może być chęć posiadania kontroli nad wszystkimi etapami, które umożliwią później również jego zastosowanie wojskowe. Zob.: M. Fitzpatrick, The Iranian Nuclear Crisis: Avoiding Worst-Case Outcomes, International Institute for Strategic Studies, Adelphi Papers 2008.

${ }^{29}$ W. L. Huntley, Rebels Without a Cause: North Korea, Iran and the NPT, „International Affairs" 2006, Vol. 82, No. 4, s. 731.

30 S. Fayazmanesh, The United States and Iran. Sanctions, wars and the policy of dual containment, London-New York 2008, s. 142-143. 
Te i inne wątpliwości oraz pytania nadal bez odpowiedzi, spowodowały przekazanie 30 stycznia 2006 r. sprawy irańskiego programu atomowego pod obrady Rady Bezpieczeństwa ONZ. Obok pięciu stałych członków w negocjacje i przygotowywanie stanowiska wobec Iranu włączone zostały Niemcy („P5+1”), wcześniej zaangażowane w ramach E3. 1 czerwca 2006 roku grupa „P5+1” w Wiedniu przedstawiła pakiet propozycji, które zawierały ofertę gospodarczą oraz deklarację pomocy w budowie reaktora na lekką wodę oraz zapowiedziała zniesienie sankcji dotyczących części zamiennych do irańskich samolotów pasażerskich. W propozycji nie wykluczono także możliwości wzbogacania przez Iran uranu w przyszłości dla celów badawczych. Pakiet ten został poparty także przez USA ${ }^{31}$. Oferta nie została przyjęta przez Iran. Jednak poważniejszym błędem władz w Teheranie było odrzucenie 25 grudnia 2005 r. oferty rosyjskiej dotyczącej wzbogacania uranu na terytorium Federacji Rosyjskiej. Z kolei interesy energetyczne ChRL w Azji Centralnej wymagały także współpracy z Rosją, wspieranie sztywnego stanowiska władz irańskich, zwłaszcza po odrzuceniu przez nie rosyjskiej propozycji mogło pokazywać, że Chiny stawiają się w opozycji wobec pozostałych członków RB ONZ ${ }^{32}$. Zatem kalkulacje władz irańskich, tak wyraźnie akcentowane od 2005 r. przez prezydenta Mahmuda Ahmedineżada i jego otoczenie, że władze Rosji i ChRL będą bezwarunkowo wspierać Iran, by osłabić wpływy amerykańskie w Zatoce Perskiej, tylko po części okazały się uzasadnione. Prezydent Iranu liczył na to, że ChRL i Rosja zablokują jakikolwiek projekt rezolucji w sprawie Iranu w RB ONZ. Jak się okazało, oba te państwa nie wykluczyły poparcia dla projektowanych sankcji wobec Iranu, jeśli nie miały poważniejszego wpływu na jego gospodarkę.

Problem irańskiego programu atomowego został zauważony przez RB ONZ, która już 31 lipca 2006 roku przyjęła rezolucję nr 1696 dającą władzom w Iranie miesiąc do zawieszenia wzbogacania uranu. Po nie zastosowaniu się przez Iran do tego terminu, 23 grudnia 2006 r. RB przyjęła pierwszy pakiet sankcji bardziej sygnalizujących problem, aniżeli dotkliwie godzących w irańskie przedsiębiorstwa. Sankcjami nie objęto inwestycji związanej z budową reaktora atomowego w Buszerze, który powstawał dzięki współpracy z Rosją. W kolejnych rezolucjach nr 1747 i 1803 rozszerzono zakres sankcji. W rezolucji nr 1835 wezwano Iran do zastosowania się wobec poprzednich rezolucji. Nie nałożono dodatkowych sankcji, wyrażono natomiast gotowość do podjęcia rozmów z władzami irańskimi. W wrześniu 2009 r. niedaleko Kom ujawniony został obiekt do wzbogacania uranu w Fordow. Władze irańskie stały na stanowisku, że zgodnie z porozumieniem o zabezpieczeniach z MAEA, miały czas do ujawniania obiektu 180 dni przed przyjęciem rozszczepialnego materiału, natomiast według MAEA, zgodnie z umową z 2003 r. Iran zobligowany był do ujawnienia informacji już w momencie planowania tego ośrodka ${ }^{33}$.

31 B. Ćwioro, Międzynarodowe wysiłki na rzecz powstrzymania irańskiego programu atomowego, Warszawa 2009, s. 112-115.

32 J. Wolska, Próby ograniczenia rozwoju militarnego komponentu irańskiego programu nuklearnego w polityce Unii Europejskiej w latach 2003-2011, „Rocznik Bezpieczeństwa Międzynarodowego" 2011/1012, s. 247.

33 Board of Governors IAEA, Implementation of the NPT Safeguards Agreement and relevant provisions of Security Council resolutions 1737 (2006), 1747 (2007), 1803 (2008) and 1835 (2008) in the Islamic Republic of Iran, 16 November 2009, http://www.iaea.org/Publications/Documents/Board/2009/gov2009-74.pdf (27.02.2013). 
W czerwcu 2010 r. w rezolucji RB ONZ nr 1929 rozszerzono i wzmocniono reżim sankcji. Nadal nie były one jednak w stanie wyrządzić poważniejszych szkód gospodarce, handlowi czy finansom Iranu, bo nie ograniczały eksportu irańskiej ropy. W tabeli 1 przestawiono rezolucje RB ONZ od 1696 do 1929 w sprawie irańskiego programu atomowego.

Tabela 1

\section{Rezolucje RB ONZ w kwestii irańskiego programu}

\begin{tabular}{|c|c|}
\hline $\begin{array}{l}\text { Rezolucja } 1696 \\
\text { z } 31 \text { lipca } 2006 \text { r. }\end{array}$ & $\begin{array}{l}\text { W rezolucji zwrócono się do Iranu o wstrzymanie wzbogacania uranu do } 31 \text { sierpnia } 2006 \mathrm{r} \text {. } \\
\text { i w przypadku niewypełnienia jej, zagrożono sankcjami. }\end{array}$ \\
\hline $\begin{array}{l}\text { Rezolucja } 1737 \\
\text { z } 23 \text { grudnia } 2006 \text { r. }\end{array}$ & $\begin{array}{l}\text { Nałożono na wszystkich członków ONZ zakaz sprzedaży Iranowi materiałów lub techno- } \\
\text { logii, które mogą zostać wykorzystane w irańskim programie jądrowym } \\
\text { i rakietowym. Z zakazu wyłączona została Federacja Rosyjska, zaangażowana w budowie } \\
\text { w Buszerze pierwszej irańskiej elektrowni jądrowej. Zamrożono też zagraniczne aktywa } \\
\text { dziesięciu irańskich firm związanych z przemysłem jądrowym. }\end{array}$ \\
\hline $\begin{array}{l}\text { Rezolucja } 1747 \\
\text { z } 24 \text { marca } 2007 \text { r. }\end{array}$ & Rozszerzenie zakresu sankcji i m.in. nałożenie embarga na eksport broni z Iranu. \\
\hline $\begin{array}{l}\text { Rezolucja } 1803 \\
\text { z } 3 \text { marca } 2008 \text { r. }\end{array}$ & $\begin{array}{l}\text { Kolejne rozszerzenie listy osób i instytucji, wobec których wprowadzono sankcje finan- } \\
\text { sowe oraz ograniczenia podróży irańskich urzędników nadzorujących program atomowy. } \\
\text { Równocześnie w dokumencie zwrócono uwagę na możliwość powrotu do dialogu, pod- } \\
\text { kreślając iż społeczność międzynarodowa nie ma nic przeciwko cywilnemu programowi } \\
\text { atomowemu. }\end{array}$ \\
\hline $\begin{array}{l}\text { Rezolucja } 1835 \\
\text { z } 27 \text { września } 2008 \text { r. }\end{array}$ & $\begin{array}{l}\text { RB ONZ wezwała Iran do zastosowania się do poprzednich rezolucji, nie nakładając no- } \\
\text { wych sankcji i potwierdzono gotowość do dialogu z władzami irańskimi. }\end{array}$ \\
\hline $\begin{array}{l}\text { Rezolucja } 1929 \\
\text { z } 9 \text { czerwca } 2010 \text { r. }\end{array}$ & $\begin{array}{l}\text { Podkreślono w rezolucji, że Iran nie podporządkował się do poprzednich rezolucji. W re- } \\
\text { zolucji nawoływano do tego, aby państwa monitorowały transakcje z irańskimi bankami, } \\
\text { także bankiem centralnym Iranu, aby zapobiegać przyczynianiu się do działań nuklear- } \\
\text { nych Iranu. Nałożono zakaz wobec Iranu nabywania udziałów w jakiejkolwiek zagranicz- } \\
\text { nej działalności komercyjnej w zakresie górnictwa uranu, produkcji lub zastosowania } \\
\text { materiałów i technologii nuklearnej lub technologii rakiet balistycznych. Państwa mają } \\
\text { dokonywać inspekcji transportów kierujących się do/z Iranu jeśli zaistnieją uzasadnione } \\
\text { podstawy by sądzić, że zawierają one zakazane towary. Państwa mają zapobiegać udziela- } \\
\text { niu usług finansowych mogących przyczyniać się do działań nuklearnych Iranu. Państwa } \\
\text { mają zapobiegać otwieraniu na ich terytoriach nowych oddziałów, filii lub biur przedsta- } \\
\text { wicielskich irańskich banków, a także zapobiegać ich współpracy z bankami narodowymi } \\
\text { jeśli mogłoby to przyczyniać się do działań nuklearnych Iranu. }\end{array}$ \\
\hline
\end{tabular}

Źródło: Opracowanie własne na podstawie: United Nations Security Council Resolution 1696, 1737, 1747, 1803, 1835, 1929, http://www.un.org (10.02.2013).

Sankcje nie doprowadziły władz irańskich do całkowitego zawieszenia procesu wzbogacania uranu. Nie doszło także do przerwania współpracy Iranu z MAEA, która znalazła się przez jakiś czas w kryzysie w związku z kontrowersjami wokół nowego obiektu do wzbogacania uranu w Fordow. Władze Iranu nadal podkreślały, że program atomowy nie służy do celów militarnych. Budzący niepokój był zakres programu oraz wiele ośrodków z nim związanych. Od wielu lat nurtowało amerykański wywiad - czy pod pretekstem cywilnego nie jest rozwijany militarny program atomowy. Po doświadczeniach z niepotwierdzonymi informacjami na temat irackiego programu atomowego, agencje związane w wywiadem USA były znacznie bardziej ostrożne w ocenie postępów programu atomowego Iranu. W wydanym w listopadzie 2007 r. raporcie narodo- 
wej rady wywiadu USA stwierdzono, że Iran najprawdopodobniej w 2003 r. przerwał swój atomowy program militarny, natomiast w latach 2010-2015 może uzyskać wystarczającą ilość wzbogaconego uranu do wyprodukowania broni jądrowej ${ }^{34}$. Raport co prawda określił kilkuletnią perspektywę, w której Iran może uzyskać techniczne możliwości do wyprodukowania broni jądrowej, równocześnie podważono w tym dokumencie twierdzenie, że Iran dzieli bardzo krótki czas od wyprodukowania bomby jądrowej.

Podsumowując politykę administracji G. W. Busha wobec Iranu należy stwierdzić, że nie tylko nie udało się doprowadzić do przełomu, ale doszło nawet do jeszcze większego kryzysu. Program wzbogacania uranu nie został zwieszony, jedynym sukcesem tej administracji było zainteresowanie tym problemem RB ONZ i przyjęcie pięciu rezolucji w tej sprawie, z których trzy nakładały sankcje na Iran. W strategii USA wobec Iranu w zasadzie można było mówić o dwóch opcjach: zaostrzaniu sankcji i szukaniu poparcia dla nich także w RB ONZ oraz próba podjęcia bezpośrednich rozmów nawet bez warunków wstępnych. Wydawało się, że przełomu dokona kolejny prezydent USA Brack Obama, który jeszcze w czasie kampanii wyborczej zapowiedział zmianę nastawienia wobec Iranu i gotowość rozpoczęcia bezpośrednich rozmów z Iranem bez warunków wstępnych ${ }^{35}$. Richard N. Haass i Martin Indyk przestrzegali administrację Obamy przed popełnieniem błędów poprzedniej republikańskiej administracji i mimo wszystko rozpoczęcie bezpośrednich negocjacji z Iranem i to bez wstępnego warunku o zaprzestaniu wzbogacania uranu ${ }^{36}$. Obaj ci eksperci uważali, iż stopniowe działania dyplomatyczne mogły doprowadzić do zmniejszenia napięć i podejrzliwości, a być może doprowadzić po jakimś czasie do zaprzestania przez Iran prac nad wzbogacaniem uranu. Na doradcę sekretarza stanu, za Hillary Clinton, powołano znawcę Bliskiego Wschodu - Dennisa Rossa. Dyplomata ten, który odgrywał istotną rolę już w czasach administracji W. Clintona, uważał iż należało Iranowi przedstawić wyraźny sygnał, iż jeśli nie podejmie konstruktywnych rozmów w sprawie swojego programu atomowego, to nałożone zostaną na to państwo kolejne sankcje ${ }^{37}$. Prezydent B. Obama już w pierwszym półroczu swojego urzędowania wykonał kilka gestów wobec Iranu. 21 marca 2009 r. skierował życzenia noworoczne skierowane dla Irańczyków z okazji Nowruzu (Perskiego Nowego Roku). 4 czerwca 2009 r. wystapił z przesłaniem do muzułmanów w Kairze, w którym odniósł się do roli odegranej przez USA w obaleniu premiera Mosaddeka oraz podkreślił, że Iran ma prawo do rozwijania cywilnego programu atomowego jeśli jest on zgodny z Układem o Nieproliferacji. 31 marca $2009 \mathrm{r}$. publicznie zaprosił władze Iranu do wzięcia udziału w konferencji na temat Afganistanu. Wśród gestów prezydenta Obamy wobec władz w Iranie znalazło się również oświadczenie, że USA będą aktywnie brać udział w negocjacjach z Iranem w ramach

34 Por.: National Intelligence Estimate Iran: Nuclear Intentions and Capabilities, November 2007, http://www.dni.gov/press_releases/20071203_release.pdf. (10.03.2013).

35 Szerzej o programach polityki zagranicznej kandydatów na urząd prezydenta Stanów Zjednoczonych zob.: R. Fiedler, Foreign Policy in the US Presidential Election Campaign, „WeltTrends. Zeitschrift für internationale Politik" 2008, No. 60, s. 5-9.

${ }_{36}$ Zob.: R. N. Haas, M. Indyk, Beyond Iraq: A New U.S. Strategy for the Middle East, „Foreign Affairs" January/February 2009, Vol. 88, Issue 1.

37 K. Katzman, Iran U.S. Concerns and Policy Responses, Congressional Research Service, Washington 2009, s. 38. 
P5+1 oraz że osłabione zostaną restrykcje dotyczące kontaktów dyplomatów amerykańskich z ich irańskimi odpowiednikami.

Wydawało się, że tej administracji uda się doprowadzić do przełomu w stosunkach z Iranem. Ważne gesty, które także zostały zauważone w Iranie mogły przyczynić się do nawiązania trwałego dialogu USA z Iranem. Pomimo zmiany retoryki, nie udało się doprowadzić do poprawy atmosfery rozmów. Podejrzenia co do intencji Iranu nasiliły się z powodu nowego nie ujawnionego wcześniej ośrodka atomowego.

W celu przełamania impasu, władze Brazylii i Turcji 17 maja 2010 r. ogłosiły, że udało im się wstępnie porozumieć z Iranem (tzw. deklaracja teherańska). Władze irańskie zgodziły się na eksport swojego niskowzbogaconego uranu (3,5-5\%). Iran w zamian miał otrzymać wzbogacony uran do $20 \%$ w formie prętów paliwowych, które miały być wykorzystane w reaktorze do celów medycznych. W planowanym działaniu, Iran nie rezygnował z prac nad wzbogacaniem uranu, ale jedynie mógł go wzbogacić do poziomu $3,5-5 \%$. Inicjatywę tę początkowo poparł prezydent Obama ${ }^{38}$. Jednak USA bardziej zależało $\mathrm{w}$ tamtym czasie na doprowadzeniu do przyjęcia kolejnego pakietu sankcji przez RB ONZ. Udało się uzyskać poparcie ChRL i Rosji. Wobec formalnej akceptacji, wybrano zaostrzenie sankcji w ramach wspomnianej rezolucji nr 1929. Inicjatywa brazylijsko-turecka pomimo wstępnego jej zaakceptowania przez Iran, nie została wykorzystana jako możliwość dalszych negocjacji z Iranem. Strona amerykańska dała nawet do zrozumienia, że Iran gotowy był przyjąć ofertę Brazylii i Turcji, by uniknąć zaostrzenia sankcji przez RB ONZ. Uznano, że strategia związana z sankcjami jest najlepszą metodą wywierania presji na Iran. Rezolucja nr 1929 stwarzała podstawę dla poszczególnych państw do zaostrzenia sankcji.

W USA przyjęto Comprehensive Iran Sanctions, Accountability and Divestment Act (CISADA) wobec zagranicznych firm, które sprzedawały benzynę do Iranu oraz nałożono zakaz wobec zagranicznych instytucji finansowych zawierania transakcji na terytorium USA z bankami irańskimi z tzw. „,czarnej listy" ${ }^{\text {39 }}$. Dodatkowe sankcje w ramach rezolucji RB ONZ nr 1929 wobec Iranu wprowadziły także: Australia, Kanada, Norwegia, Korea Południowa, Japonia, Unia Europejska. Rosja i ChRL nie zamierzały skorzystać z takiej ścieżki. Zajęły stanowisko, że Iran pomimo wielu wątpliwości współpracuje nadal z MAEA. Ponadto dla przedstawicieli ChRL i Rosji, zbytnie osłabienie Iranu uderzałoby w ich interesy. Zwłaszcza dla chińskich firm związanych z sektorem energetycznym oznaczałoby to poważne kłopoty. Jak zauważyli Erica Downs i Suzanne Moloney, USA mogą stanąć przed dylematem - co zrobić z chińskimi firmami, które pomimo sankcji nadal inwestują i współpracują z różnymi instytucjami irańskimi, także tymi znajdującymi się na tzw. „czarnej liście”40. Sytuacja nie jest łatwa, sankcje nałożone na firmy chińskie, z jednej strony oznaczać będą napięcie w stosunkach USA-ChRL, a z drugiej brak reakcji ze strony administracji B. Obamy

\footnotetext{
38 K. Katzman, Iran Sanctions, Congressional Research Service, Washington, 10.01.2012, s. $35-40$.

39 Comprehensive Iran Sanctions, Accountability and Divestment Act of 2010, http://www.treasury.gov/resource-center/sanctions/Documents/hr2194.pdf (1.03.2013).

40 E. Downs, S. Moloney, Getting China to Sanction Iran, „Foreign Affairs”, March/April 2011, Vol. 90, Issue 2.
} 
będzie zniechęcające wobec tych państw, które zdecydowały się na takie zaostrzenie sankcji i być może skłoni je do wycofania się z nich, widząc straty z jednej oraz korzyści dla tych, którzy nie nałożyli tak dotkliwych sankcji z drugiej strony. Ponadto utrzymując, a nawet rozwijając współpracę z ChRL, władze w Teheranie wysyłają czytelny sygnał: „Iran już więcej nie potrzebuje Zachodu”.

Innym problemem w niełatwych relacjach z Iranem była brutalna pacyfikacja przez władze irańskie „ruchu zielonych”. W czerwcu 2009 r. miały miejsce wybory prezydenckie w Iranie, w których doszło do rywalizacji pomiędzy urzędującym prezydentem Mahmudem Ahmadineżadem oraz Mir Husajnem Musawim. Irańska opozycja zarzuciła władzom, że doszło do manipulacji przy liczeniu głosów, w której rezultacie odniósł zwycięstwo Ahmadineżad. W reakcji na pacyfikowanie demonstracji oraz aresztowanie najbardziej aktywnych ich liderów z „ruchu zielonych”, 28 września 2010 r. prezydent USA w ramach IEEPA wydał wykonawcze zarządzenie umożliwiające zablokowanie znajdujących się w USA aktywów finansowych irańskich urzędników zaangażowanych w pacyfikowanie demonstracji, a także dokonujących zakupów technologii lub innych materiałów służących do realizacji programu wzbogacania uranu. Zarządzenie uniemożliwiło także wjazd tym irańskim urzędnikom, którym zarzucono udział w nadużyciach wobec opozycji ${ }^{41}$. Krytycy tego zarządzenia podkreślali, że nie dotykało ono sprawców, dlatego iż urzędnicy irańscy w przeważającej części nie posiadali aktywów finansowych w USA, ani nie zamierzali przyjeżdżać do USA.

W ocenie administracji B. Obamy dotychczasowe sankcje uznawano za mało skuteczne, nie doprowadziły do zawieszenia prac nad wzbogacaniem uranu, ani nie osiągnięto choćby wstępnego porozumienia z grupą P5+1. Inicjatywa w sprawie wprowadzenia bardziej dotkliwych sankcji wobec Iranu podjęta została przez kongres USA. Uznano, że aby sankcje były bardziej skuteczne powinny zostać skierowane w irański sektor energetyczny. W grudniu 2011 r. została przyjęta przez amerykański kongres ustawa National Defense Authorization Act, zatwierdzona przez prezydenta, uniemożliwiająca dokonywanie transakcji przez zagraniczne banki z irańskim bankiem centralnym na terytorium USA. Sukcesem amerykańskiej administracji było nakłonienie partnerów z UE do wprowadzenia embarga na zakup irańskiej ropy. 23 stycznia 2012 r. podjęto decyzję, że państwa UE nie będą zawierać nowych kontraktów na zakup irańskiej ropy, a obecne miały zostać zakończone 1 lipca 2012 r. Ponadto w lutym 2012 r. belgijskie towarzystwo - Society for Worldwide International Financial Transfers (SWIFT) podjęło decyzję o zablokowaniu transakcji finansowych $\mathrm{z}$ bankami irańskimi. Zablokowanie transferów w ramach SWIFT objęło około 18 irańskich banków.

W sumie Iran sprzedawał do UE 600 tysięcy baryłek ropy dziennie, co wynosiło jedną czwartą jego eksportu tego surowca. W swoim wystąpieniu na początku stycznia 2013 r. minister ds. ropy Rostam Qasem oświadczył przed medżlisem, że unijne embargo oraz zablokowanie transakcji z irańskim bankiem centralnym doprowadziło w sumie do $40 \%$ spadku w eksporcie ropy, który jeszcze w $2011 \mathrm{r}$. wynosił 2,5 mln baryłek

41 Weighing Costs and Benefits of International Sanctions against Iran, The Iran Project, Washington 2012, s. 61. 
dziennie $^{42}$. Sankcje amerykańsko-unijne są odczuwalne przez gospodarkę i sektor finansowy Iranu. Władze irańskie jak dotąd nie wycofały się z prac nad wzbogacaniem uranu. Dla UE utrzymanie sankcji wobec Iranu w dłuższej perspektywie może utrudnić odzyskanie przez europejskie przedsiębiorstwa irańskiego rynku.

$$
* * *
$$

Zmiana systemu politycznego na skutek rewolucji islamskiej w Iranie oraz kryzys związany z amerykańskimi zakładnikami doprowadziły w odpowiedzi do nałożenia przez USA sankcji. Jak się okazało, mimo iż sankcje miały dotkliwy charakter nie doprowadziły do przyspieszenia rozmów w sprawie uwolnienia amerykańskich zakładników z Iranu. Pomimo tego, sankcje od roku 1979 są stale wykorzystywanym instrumentem w polityce USA wobec Iranu. Kolejne amerykańskie administracje zarzucały Iranowi aktywne wspieranie terroryzmu oraz rozwijanie pod przykrywką cywilnego - militarnego programu jądrowego. Przez dekady USA znajdowały się w osamotnieniu w wprowadzaniu kolejnych sankcji wobec Iranu. Taka polityka często spotykała się z brakiem zrozumienia także spośród najbliższych sojuszników USA. Niezadeklarowanym wprost celem jest doprowadzenie poprzez wieloletnie sankcje do zmiany politycznej w Iranie. Jak uczy przykład Iraku jest to cel bardzo trudny do osiągnięcia. Musiałyby zadziałać równocześnie dwa czynniki, sankcje oraz wzrastająca w siłę opozycja wewnątrz Iranu.

Na problem irańskiego programu atomowego zwrócono uwagę w 2006 r. poprzez sankcje przyjęte w rezolucjach RB ONZ. Wielostronny reżim sankcji może być bardziej dotkliwym instrumentem wobec irańskich aspiracji nuklearnych. Zwłaszcza rezolucja RB ONZ nr 1929 stworzyła każdemu państwu podstawę dla podjęcia dodatkowych działań wobec Iranu. Z takiej drogi skorzystały m.in. USA oraz UE. Rezolucje przyjęte przez RB ONZ w sprawie Iranu nie doprowadziły do zaniechania przez to państwo prac nad wzbogacaniem uranu. Zaostrzanie sankcji wobec Iranu nie jest brane pod uwagę przez Chiny oraz Rosję ze względu na straty gospodarcze oraz obawy przed destabilizacją teokratycznego reżimu.

UE wprowadzając embargo na zakup irańskiej ropy oraz zaostrzając sankcje wobec Iranu ponosi koszty związane z tymi działaniami. Powstaje pytanie jak długo partnerzy europejscy USA będą chcieli kontynuować tego typu politykę, zwłaszcza gdy sankcje niekoniecznie muszą doprowadzić do zmiany polityki Iranu. Istotnym czynnikiem jest nie tyle brak spójności w utrzymaniu reżimu sankcji przez stałych członków RB ONZ lecz ogromna determinacja Iranu związana z dalszym rozwojem programu atomowego. Sankcje jako instrument nacisku osłabiają gospodarkę Iranu, ale jednak nie na tyle w wystarczający sposób, aby doprowadzić do całkowitego zahamowania prac nad wzbogacaniem uranu.

Przykład Iranu ilustruje, że sankcje, choć go ograniczają, to jednak nie zablokowały jego programu atomowego. USA w nałożonych sankcjach na Iran doszły już do kresu

${ }^{42}$ K. Katzman, Iran Sanctions, op. cit. 
sowich możliwości w nakładaniu kolejnych. Przez ponad trzy dekady nie doszło do zmiany w polityce Iranu, ani w ostatnim czasie nie uzyskano choćby niewielkiego postępu w negocjacjach na temat irańskiego programu atomowego ${ }^{43}$. Uzyskanie przez Iran statusu mocarstwa atomowego może skłonić do refleksji na temat skuteczności reżimu sankcji. Być może odpowiedzią może być przytoczona wcześniej konstatacja Davida Baldwina, że państwa mimo nieskuteczności sankcji będą je nakładać, by uniknać kosztownej i ryzykownej interwencji militarnej. Takim przykładem może być Korea Północna.

\title{
STRESZCZENIE
}

W artykule omówiono sankcje jako instrument wykorzystywany w polityce USA wobec Iranu. Zarzutami podnoszonymi przez USA wobec Iranu jest wspieranie terroryzmu oraz intensywnie rozwijany program atomowy. Po roku 2006 zostały nałożone: sankcje przez Radę Bezpieczeństwa ONZ oraz embargo UE na zakup irańskiej ropy. Kolejne reżimy sankcji nie doprowadziły ani do zmiany polityki Iranu, ani do zmian politycznych w tym państwie. Ukazano problem skuteczności sankcji, zwłaszcza gdy nie wszystkie państwa godzą się na ich zaostrzenie, a władze Iranu są zdeterminowane w dalszym rozwijaniu programu atomowego bez względu na koszty, potępienie i kolejne sankcje.

\section{FROM SANCTIONS TO SANCTIONS. UNITED STATES POLICY TOWARDS IRANIAN ISLAMIC REPUBLIC}

\begin{abstract}
The article presents sanctions as an instrument in the United States policy to Iran. Washington accuses Iran for sponsoring terrorism and developing intensively its nuclear program. Since 2006 sanctions have been imposed by the United Nation's Security Council and additionally and the European Union has imposed embargo on buying Iran's oil. Each of these imposed sanctions regimes against Iran do not bring to a desirable change in Iran's policy. The article focuses on the problem of sanctions effectiveness, especially in the situation in which not all states agree in imposing hard sanctions and Iran is strongly determined in further developing its nuclear program despite of costs and condemnation and further sanctions.

43 Szerzej: S. Maloney, Obama's Counterproductive New Iran Sanctions. How Washington is Sliding Toward Regime Change, „Foreign Affairs”, 5.01.2012, http://www.foreignaffairs.com/articles/137011/suzanne-maloney/obamas-counterproductive-new-iran sanctions (14.03.2013).
\end{abstract}

